\title{
Emergency endovascular treatment of a ruptured external carotid artery pseudoaneurysm caused by a cervical stab wound: A case report and literature review
}

\author{
Junya Tsurukiri, M.D., ${ }^{1}$ Eitaro Okumura, M.D., ${ }^{1}$ Hiroshi Yamanaka, M.D., ${ }^{1}$ \\ Hiroyuki Jimbo, M.D., ${ }^{2}$ Akira Hoshiai, M.D. ${ }^{1}$ \\ ${ }^{1}$ Department of Emergency and Critical Care Medicine, Tokyo Medical University Hachioji Medical Center, Tokyo-Japan \\ ${ }^{2}$ Department of Neurosurgery, Tokyo Medical University Hachioji Medical Center, Tokyo-Japan
}

\begin{abstract}
The formation of external carotid artery (ECA) pseudoaneurysms caused by stab wounds is a rare vascular anomaly. Although the surgical exploration of the ECA segment is the standard treatment, endovascular treatment (EVT) can be considered if there is difficulty in identifying the source of bleeding in the injured regions that are difficult to operatively access. Here we treated a young patient who had hemorrhagic instability with hemorrhage-induced coagulopathy caused by a zone III cervical stab wound with a pseudoaneurysm from the main trunk of the ECA; the patient underwent EVT and successful hemostasis. A literature review based on the data available on PubMed was conducted, and 15 published reports of 82 penetrating ECA injuries treated by EVT were identified. We concluded that EVT appears to be an effective surgical alternative for patients with hemorrhage-induced coagulopathy caused by a ruptured ECA pseudoaneurysm after a cervical stab wound.
\end{abstract}

Keywords: Bleeding; injury; interventional radiology; penetrating; shock.

\section{INTRODUCTION}

Pseudoaneurysms occur as a result of total or partial disruption of the arterial wall, with the formation of a hematoma and organization. Trauma can cause disruption of the vessel wall, with extravasation of blood and formation of a hematoma and pseudocapsule that can expand because of blood pressure. ${ }^{[1]}$ Carotid artery (CA) injuries occur more commonly due to blunt trauma, and CA pseudoaneurysms are often the result of blunt trauma in zone II of the neck. ${ }^{[2,3]}$ Penetrating CA injuries have been reported to account for only $3 \%$ of arterial injuries. ${ }^{[4]}$ Although the internal $C A$ is more commonly injured during trauma, there are few reports on ECA injuries that have lower incidences. ${ }^{[5]}$ External CA (ECA) injuries caused

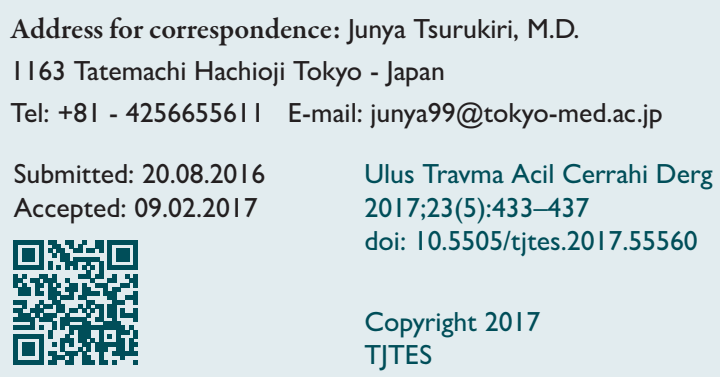

by cervical stab wounds sometimes become life threatening, and the formation of ECA pseudoaneurysms caused by stab wounds is a rare vascular anomaly. ${ }^{[1]}$ There are insufficient data regarding endovascular treatment (EVT) of penetrating ECA pseudoaneurysms.

We report the case of a young patient with hemorrhagic instability caused by cervical stab wounds and who underwent EVT for a ruptured ECA pseudoaneurysm.

\section{CASE REPORT}

A 25-year-old man was admitted to our emergency department with hemorrhagic shock after a cervical stab wound. His past medical history included developmental disability. His physical examination revealed a Glasgow Coma Scale score of 7 (eye $=2$, verbal $=1$, and motor $=4$ ), blood pressure of $63 / 20 \mathrm{mmHg}$, and heart rate of 91 beats $/ \mathrm{min}$. Bleeding from two areas of a $6-\mathrm{cm}$ stab wound at zone III of his left neck was continuous. The patient was hemodynamically unstable and immediately received initial trauma resuscitation. The hemoglobin level, hematocrit, prothrombin time/international normalized ratio, and lactate level were $6.8 \mathrm{~g} / \mathrm{dL}$ [reference range (RR), $13.5-17.5 \mathrm{~g} / \mathrm{dL}$ ], $19 \%$ (RR, 39\%-52\%), I.66, and 
$6.2 \mathrm{mmol} / \mathrm{L}$ (RR, $2.0-5.0 \mathrm{mmol} / \mathrm{L}$ ), respectively. After the rapid administration of Ringer's lactate solution and blood transfusion, his blood pressure improved. Contrast-enhanced computed tomography (CECT) of the neck revealed remarkable bleeding and demonstrated contrast medium extravasation and a pseudoaneurysm arising from the left ECA (Fig. Ia). After CECT, his blood pressure fell to $86 / 36 \mathrm{mmHg}$. We believed that it would be difficult to secure and maintain a visual field during surgery for the patient in this condition; therefore, we decided to perform EVT for achieving hemostasis.

EVT was performed under general anesthesia. Angiography revealed pseudoaneurysm formation with contrast medium extravasation from the left ECA distal to the origin of the facial artery (Fig. Ib). The distal trunk of the ECA was collaterally supplied by branches of the ascending pharyngeal artery. A microcatheter (Headway, Termo, Tokyo, Japan) was selectively placed into the center of the pseudoaneurysm; this was followed by coil embolization using $4 \mathrm{~mm} \times$ $6 \mathrm{~cm}, 3.5 \mathrm{~mm} \times 8 \mathrm{~cm}$, and $3.5 \mathrm{~mm} \times 8 \mathrm{~cm}$ microcoils (ED Coil Complex, Kaneka Medics Corporation, Osaka, Japan) deployed in the pseudoaneurysm. Furthermore, $0.6 \mathrm{~mL}$ of $\mathrm{N}$ butyl cyanoacrylate (NBCA) (Histoacryl; Braun, Melsungen, Germany), which was mixed with iodized oil (Lipiodol; Andre Guerbet, Aulnay-sous-Bois, France) at a ratio of I:I, was carefully injected because bleeding was continuous (Fig. Ic). EVT was successful, and the pseudoaneurysm was undetectable thereafter (Fig. Id). A total of $1600 \mathrm{~mL}$ of red blood cells and $800 \mathrm{~mL}$ of fresh frozen plasma was administered within $24 \mathrm{~h}$. Three days later, none of the images revealed dilatation or disruption of the ECA wall (Fig. Ie, f). The patient was discharged from the hospital 14 days after admission without any complications (Fig. Ig).

\section{DISCUSSION}

In a search of the literature using Medline, 15 published reports of 82 penetrating ECA injuries that underwent EVT were identified (Table I). ${ }^{[1,6-19]}$ Twenty-four patients had pseudoaneurysms at the ECA, and gunshots were the main cause of pseudoaneurysm formation in the ECA. The ECA and its branches are protected from external force by soft tissues until the artery emerges at the superior temporal line of the skull. Although injuries to the branches of the ECA are considerably more common than those to the main trunk of the $E C A$, the main trunk of the ECA is one of the most common parent arteries pertaining to the pseudoaneurysm. Bleeding from wounds is the main clinical sign after injury. Upon reviewing the existing literature, almost all patients underwent EVT using fibered coil embolization and showed good out-
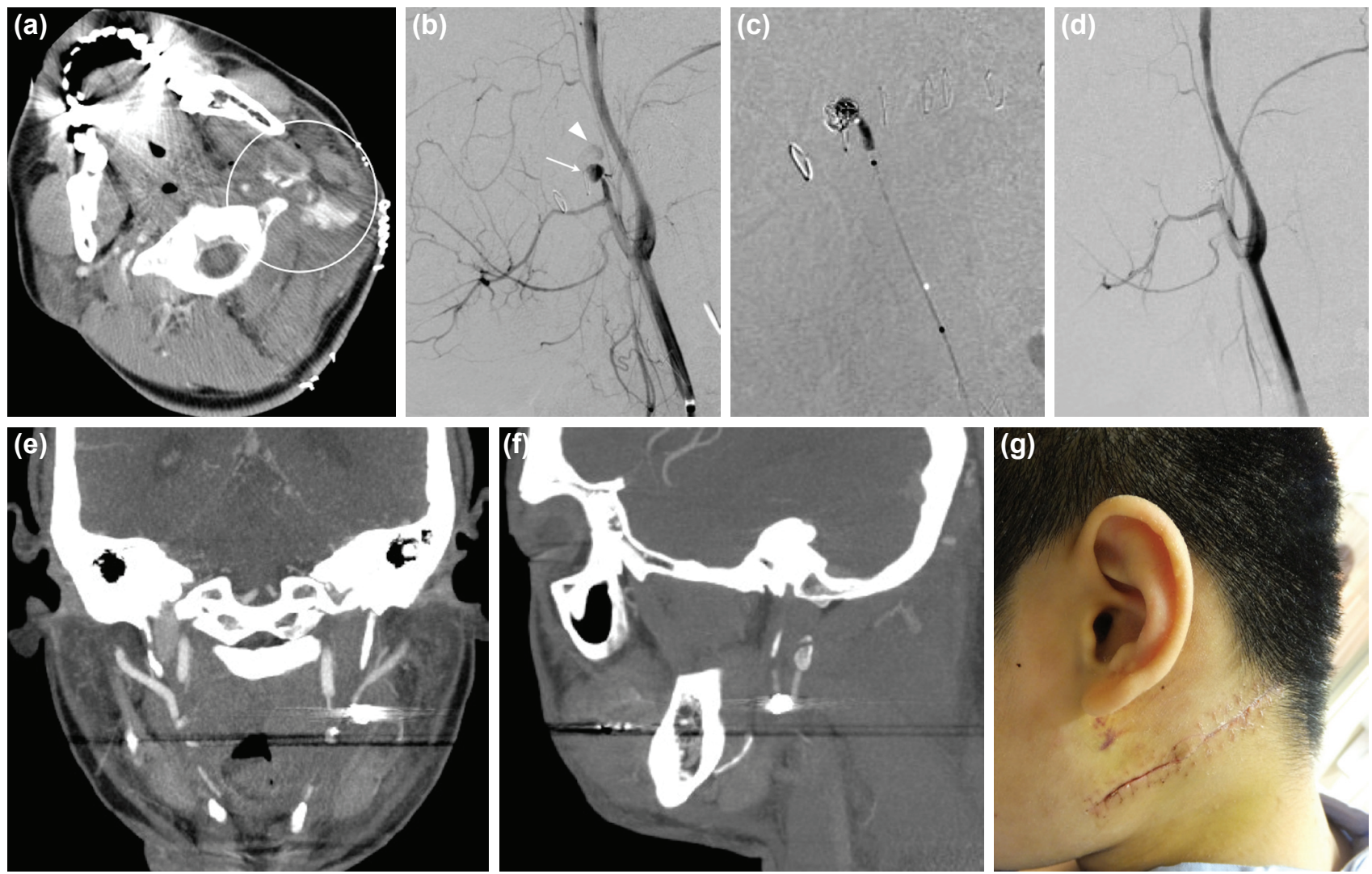

Figure 1. (a) Computed tomography images with massive contrast medium extravasation (circle). (b) Angiography revealed a pseudoaneurysm (arrow) with contrast medium extravasation (arrow head) from the proximal trunk of the external carotid artery distal to the origin of the facial artery. (c) Coil embolization using an ED coil complex and the injection of N-butyl cyanoacrylate. (d) Completion of hemostasis. Contrast-enhanced CT revealed no dilatation or disruption of the arterial wall at the external carotid artery. (e) Coronal image; (f) sagittal image. (g) The wound was healed after suturing. 


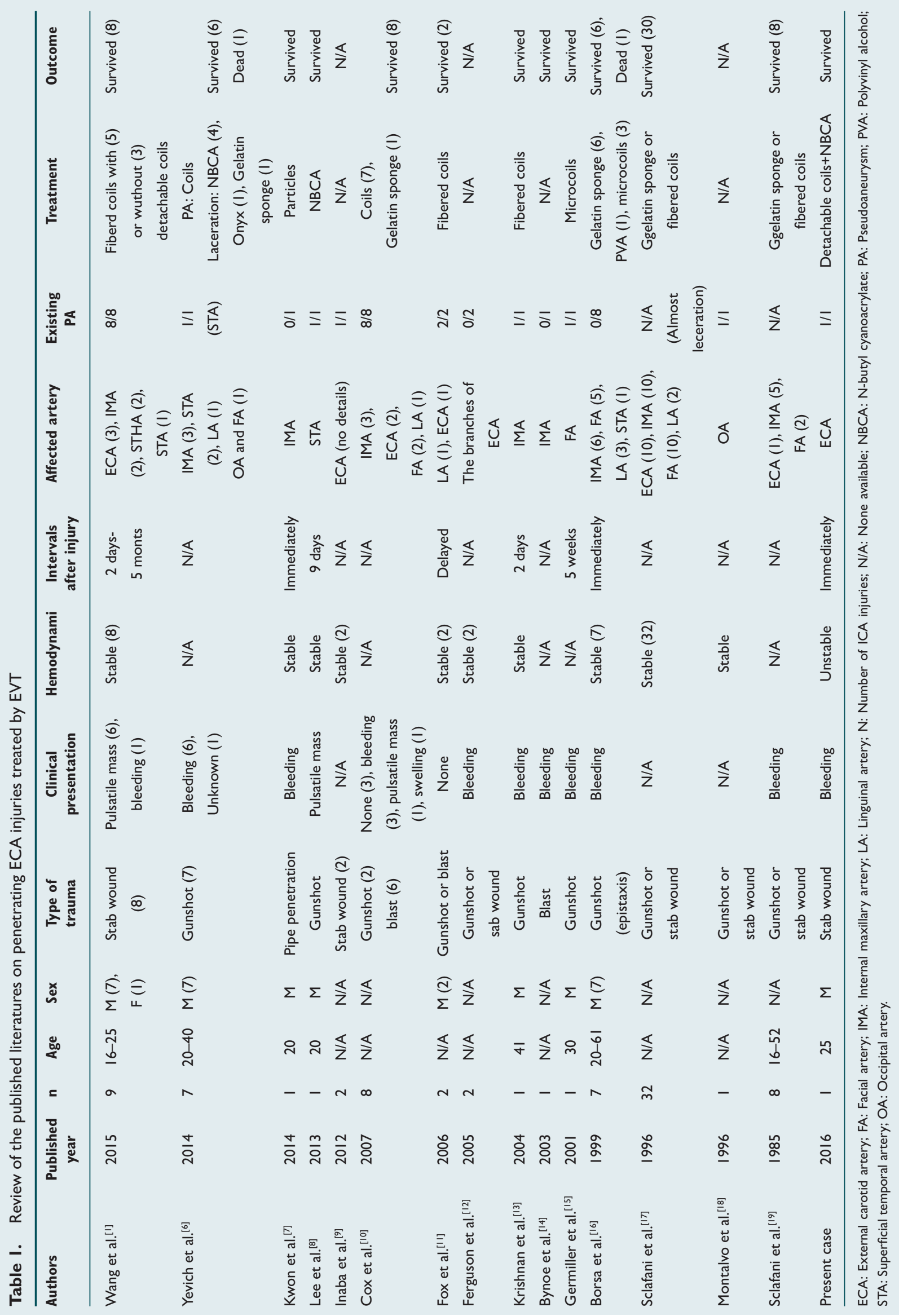


comes. However, re-bleeding and facial nerve palsy after EVT were also reported. ${ }^{[20]}$

Although the standard treatment is surgical ligation and resection of the ECA segment without the need for reconstruction, EVT can be considered if there is difficulty in identifying the source of bleeding for injured regions that are difficult to operatively access, particularly in deeply located vessels injured by cervical stab wounds. The development of endovascular equipment has contributed to the acceptance of EVT as an effective and safe treatment, and various embolic materials are now available. Gelatin sponge particles are divided into temporary embolic agents. Alternatively, microcoils and NBCA are divided into permanent embolic agents. The use of gelatin sponge particles or coils involves the physical blocking of blood flow with thrombus formation in the vascular lumen. NBCA is routinely used by mixing it with iodized oil to make it radiopaque, and an operator can adjust the extent of embolization by changing the mixing ratio. The use of NBCA in an animal model of hemorrhage-induced coagulopathy and various nontraumatic situations was demonstrated. ${ }^{[21,22]}$ An 0.010-inch ED Coil Complex is a ready available electrical detachable coil and has a more complex outward shape and softer flexibility than conventional helical ED coils. We used these coils because the pseudoaneurysm was continuously bleeding and very fragile; coil deployment was successful. Furthermore, we added the proximal ECA occlusion using NBCA with technically success.

\section{Conclusion}

EVT appears to be an effective surgical alternative for patients with hemorrhage-induced coagulopathy caused by ruptured ECA pseudoaneurysms after cervical stab wounds.

\section{Consent}

Written informed consent was obtained from the next of kin of the patient for publication of this case report and accompanying images.

Conflict of interest: None declared.

\section{REFERENCES}

1. Wang D, Su L, Han Y, Fan X. Embolization treatment of pseudoaneurysms originating from the external carotid artery. J Vasc Surg 2015;61:920-6. [CrossRef]

2. Davis JW, Holbrook TL, Hoyt DB. Blunt carotid artery dissection: incidence, associated injuries, screening and treatment. J Trauma 1990;30:1514-417. [CrossRef]

3. Bayır A, Aydoğdu KireșI D, Söylemez A, Demirci O. Cerebral infarction caused by traumatic carotid artery dissection. Ulus Travma Acil Cerrahi Derg 2012;18:347-50. [CrossRef]

4. Bodanapally UK, Dreizin D, Sliker CW, Boscak AR, Reddy RP. Vascular Injuries to the Neck After Penetrating Trauma: Diagnostic Per- formance of 40- and 64-MDCT Angiography. AJR Am J Roentgenol 2015;205:866-72. [CrossRef]

5. Mattox KL, Feliciano DV, Burch J, Beall AC Jr, Jordan GL Jr, De Bakey ME. Five thousand seven hundred sixty cardiovascular injuries in 4459 patients. Epidemiologic evolution 1958 to 1987. Ann Surg 1989;209:698-7. [CrossRef]

6. Yevich SM, Lee SR, Scott BG, Shaltoni HM, Mawad ME, Benndorf. Emergency endovascular management of penetrating gunshot injuries to the arteries in the face and neck: a case series and review of the literature. J NeuroIntervent Surg 2014;6:42-6. [CrossRef]

7. Kwon B, Chang HW, Kim SJ, Sohn SL, Choi TH. Penetrating facial injury. Emerg Med J 2014;31:774. [CrossRef]

8. Lee SR, Metwalli ZA, Yevich SM, Whigham CJ, Benndorf G. Variability in evolution and course of gunshot injuries to the neck and impact on management. A case report. Interv Neuroradiol 2013;19:489-95.

9. Inaba K, Branco BC, Menaker J, Scalea TM, Crane S, DuBose JJ, et al. Evaluation of multidetector computed tomography for penetrating neck injury: A prospective multicenter study. J Trauma 2012;72:576-84.

10. Cox MW, Whittaker DR, Martinez C, Fox CJ, Feuerstein IM, Gillespie DL. Traumatic pseudoaneurysms of the head and neck: Early endovascular intervention. J Vasc Surg 2007;46:1227-33. [CrossRef]

11. Fox CJ, Gillespie DL, Weber MA, Cox MW, Hawksworth JS, Cryer CM, et al. Delayed evalustion of combat-related penetrating neck trauma. J Vasc Surg 2006;44:86-93. [CrossRef]

12. Ferguson E, Dennis JW, Vu JH, Frylberg ER. Redefining the role of arterial imaging in the management of penetrating zone 3 neck injuries. Vascular 2005;13:158-63. [CrossRef]

13. Krishnan DG, Marashi A, Malik A. Pseudoaneurysm of internal maxillary artery secondary to gunshot wound managed by endovascular technique. J Oral Maxillofac Surg 2004;62:500-2. [CrossRef]

14. Bynoe RP, Kerwin AJ, Parker HH, Nottingham JM, Bell RM, Yost MJ, et al. Maxillofacial injuries and life-threatening hemorrhage: treatment with transcatheter arterial embolization. J Trauma 2003;55:74-9. [CrossRef]

15. Germiller JA, Myers LL, Harris MO, Bradford CR. Pseudoaneurysm of the proximal facial artery presenting as oropharyngeal hemorrhage. Head Neck 2001;23:259-63. [CrossRef]

16. Borsa JJ, Fontaine AB, Eskridge JM, Song JK, Hoffer EK, Aoki AA. Transcatheter arterial embolization for intractable epistaxis secondary to gunshot wounds. J Vasc Interv Radiol 1999;10:297-302. [CrossRef]

17. Sclafani AP, Sclafani SJ. Angiography and trancatheter arterial embolization of vascular injuries of the face and neck. Laryngoscope 1996;106:168-73. [CrossRef]

18. Montalvo BM, LeBlang SD, Nunez DB, Ginzburg E, Klose KJ, Becerra $\mathrm{JL}$, et al. Color doppler sonography in penetrating injuries of the nack. AJNR Am J Neuroradiol 1996;17:943-51.

19. Sclafani SJ, Panetta T, Goldstein AS, Phillips TF, Hotson G, Loh J, et al. The management of arterial injuries caused by penetrating of Zone III of the Neck. J Trauma 1985;25:871-81. [CrossRef]

20. Rhee CS, Jinn TH, Jung HW, Sung MW, Kim KH, Min YG. Traumatic pseudoaneurysm of the external carotid artery with parotid mass and delayed facial nerve palsy. Otolaryngol Head Neck Surg 1999;121:158-60.

21. Yonemitsu T, Kawai N, Sato M, Sonomura T, Takasaka I, Nakai M, et al. Comparison of hemostatic durability between N-Butyl Cyanoacrylate and gelatin sponge particles in transcatheter arterial embolization for acute arterial hemorrhage in a coagulopathic condition in a swine model. Cardiovasc Intervent Radiol 2010;33:1192-7. [CrossRef]

22. Igarashi S, Izuchi S, Ogawa Y, Yoshimathu M, Takizawa K, Nakajima Y, et al. N-butyl cyanoacrylate is very effective for massive hemorrhage during the perinatal period. PLoS ONE 2013;8:e77494. [CrossRef] 


\section{OLGU SUNUMU - ÖZET}

\section{Servikal penetran yaranın neden olduğu eksternal karotis arter psödoanevrizması rüptürünün acil endovasküler tedavisi: Bir olgu sunumu ve literatürün gözden geçirilmesi Dr. Junya Tsurukiri, ${ }^{1}$ Dr. Eitaro Okumura, ${ }^{1}$ Dr. Hiroshi Yamanaka, ${ }^{1}$ Dr. Hiroyuki Jimbo, ${ }^{2}$ Dr. Akira Hoshiai ${ }^{1}$}

${ }^{1}$ Tokyo Tıp Üniversitesi Hachioji Tıp Merkezi, Acil ve Kritik Bakım Kliniği, Tokyo-Japonya ${ }^{2}$ Tokyo Tıp Üniversitesi Hachioji Tıp Merkezi, Nöroşirurji Kliniği, Tokyo-Japonya

Penetran yaralanmanın neden olduğu eksternal karotis arter (EKA) psödoanevrizmaları seyrek görülen bir vasküler anomalidir. Eksternal karotis arter segmentinin eksplorasyonu standart tedavi olmasına rağmen, cerrahi olarak ulaşılması zor alanda kanamanın kaynağını bulmada zorluk varsa endovasküler tedavi (EVT) düşünülebilir. Burada EKA'nın ana gövdesinde psödoanevrizmalı III. zon boyun penetran yarasının neden olduğu kanamanın neden olduğu koagülopatiyle birlikte kanaması durdurulamayan genç bir hastayı tedavi ettik. Hasta başarılı hemostazın sağlandığı EVT geçirmiştir. PubMed verilerine dayanan literatür derlemeleri sonucu EVT ile tedavi edilmiş penetran EKA yaralanmalarına ait I 55 yayınlanmış olgu raporu saptanmıştır. Endovasküler tedavinin, boyunda penetran yaralanma sonrası oluşan rüptüre EKA psödoanevrizmasının yol açtığı kanamanın neden olduğu koagülopati hastalarında etkili bir alternatif cerrahi tedavi olduğu kararına vardık.

Anahtar sözcükler: Boyun; girişimsel radyoloji; kanama; penetran; silahla yaralanma; şok; yaralanma.

Ulus Travma Acil Cerrahi Derg 2017;22(5):433-437 doi: 10.5505/tjtes.2017.55560 